\title{
Network Society and Social Movement: Message Reception among Instagram Users
}

\author{
http://dx.doi.org/10.25008/jkiski.v5i2.382
}

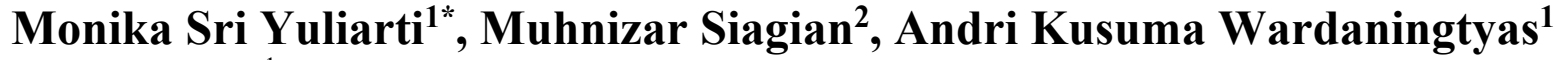 \\ ${ }^{1}$ Department of Communication Science, Universitas Sebelas Maret \\ ${ }^{2}$ Department of International Relations, Universitas Sebelas Maret \\ Jl. Ir. Sutami No. 36A Surakarta - Indonesia \\ *Corresponding author: monika.yuliarti@staff.uns.ac.id
}

\author{
Submitted: June 24, 2020, Revised: November 25, 2020, Accepted: December 17, 2020 \\ Accredited by Kemristekdikti No. 28/E/KPT/2019
}

\begin{abstract}
In the dynamics of a state, any change can happen through a social movement as an initial stage. Studies about it have been conducted since the 1940s. Nowadays, as the shift of the era involves communication technology, the model of the social movement has changed as well. Collectivity dominated the social movement in the past, but connectivity is more prominent nowadays as the network society era emerges. The purpose of this research is to explore the social movement in the network society era through an Instagram account, @ aketimbang.ngemis.yogyakarta along with the message reception among the Instagram users. Using Stuart Hall's theory of message reception, this study employed snowball as the technique sampling. After analyzing five posts on@ketimbang.ngemis.yogyakarta Instagram account and having an interview with eight informants, there were two conclusions. It is found that there is a shift in the model of social movement. In the past, social movements were dominated by demonstrations, in which a group of people gathered in a particular place, and relied on oratory skills. Meanwhile, at present, many social movements have made use of social media, one of which is Instagram. The photos in Instagram are used to show marginalized groups which can attract sympathy, empathy, and attention of social media users as an initial stage to the social movement. Moreover, the social media users tend to be a negotiated code type in the reception of social movement message.

Keywords: Social movement; network society; Instagram; message reception;
\end{abstract}

\section{Introduction}

In a dynamic life, change is something inevitable. In the context of a state, change can occur because of social movements. Studies have been conducted on the consequences of social movements which are state-related, including legislative area (Amenta \& Caren, 2006). Although defining the term social movement is not easy to do, the study of social movements has existed since the late 1940s, though with a note of "the level of crude descriptive understanding and lack of theory". This is natural, because events were believed to be a popular form of social movement at least around the end of the 1960s. At that time, the world underwent a very profound dramatic transformation, which some experts called a revolution, which was very well known as the French Revolution in 1968 (Nash, 2004) .

The study of social movements that have existed since the 1940s is a study of social movements that fall into the classification of classical and neo-classical traditions. During this era, movements took place spontaneously, with lack of proper planning, whether in terms of organization, strategy or tactics. Some examples of social movements at that time included the slave uprisings in Ancient Rome and the peasant revolts in medieval Germany (Berberoglu, 2019). This long period of social movement studies gained the influence of thought from the perspective of classical social psychology with the characteristic of irrational actions. 
Individuals who take part in a movement in the form of action groups such as revolts, riots, and political riots (mob), and so on. Furthermore, the phenomenon of social movements that occurred in the 1970s showed that individual and collective behavior in various movements that occurred was rational and sane-minded actions and the actions taken were carefully calculated. The actors and members of the movement were clear people, have a broad insight and clear future vision that is carefully calculated in the movements carried out. This social movement is known as the new era of social movements. Judy Butler was one of the scientists that focused on it, with her insight on feminism and the gay and lesbian movement (Reinmurth, 2016).

In Indonesia, discussing social movements certainly cannot be separated from the 1998 Reformation which succeeded in overthrowing the Soeharto regime which had been in power for more than 30 years. Prior to the end of Soeharto presidency, several efforts had been made, particularly in term of disseminating some information regarding his wealth, which became one of the triggers for many university students and ordinary people to launch a real mass-based antihegemonic movement (Lim, 2003). With the practice of military violence which resulted in the killing of several students during the protests, a very intense social movement echoed among civilians, which in turn gave rise to a very authentic political revolution. Ultimately, Suharto resigned from his position as president on May 21, 1998. Furthermore, social movements also change, along with the changing era. The social movements not only take place physically, where many people gather and have a direct contact with each other and also with the government, but also involve some advance tools, devices with internet connection

Today, the internet has entered human life and in Indonesia, the growth of its users is quite significant. Data from We Are Social and Hootsuite show that in January 2020, there were 175.4 million internet users in Indonesia, with $64 \%$ penetration. Compared to data in the previous year, there was an increase of about $17 \%$ (Kemp, 2020). Moreover, data from the Polling Indonesia and Indonesian Internet Service Providers Association in 2018 show that internet users in Indonesia increased $10 \%$ compared to 2018 . This study showed that 171 million people, or $64.8 \%$ of the total Indonesian population of 264 million, were connected to the internet in 2018 , so, there was an increase from the data in 2017 which was only $54.86 \%$ (The Jakarta Post, 2019).

In Indonesia, there were 160 million social media users in January 2020. The number of social media users in Indonesia increased by 12 million (+8.1\%) between April 2019 and January 2020. Youtube is the most popular social media in Indonesia, where $88 \%$ of the entire population use it. Whatsapp and Facebook follow behind it, and Instagram is the 4th most popular social media with a penetration of $79 \%$ (Kemp, 2020).

With the shift of the era, which involves communication technology, the shift of the social movement model is inevitable. In the past, the collective movement dominated social movement model. However, since the emergence of the social media that allows everyone to connect more intensively, the term network society emerges (Castells, 2005). In this era, many social movements are carried out using social media, one of which is Instagram (Parahita, 2019). As a platform that can establish relationships between users, Instagram is widely used by users, both individuals, and organizational users. There is no longer a collectivistic in the social movement like in the past, but the connectivity is more dominant.

However, one of the effects of the increasing use of social media among the community, especially adolescents, is the reduction in direct interaction between people (Subramanian, 2017), which enables a decrease in social awareness. On the other hand, the world still leaves social problems that need solutions. One of the things that can be the beginning of the solution to these social problems is sensitivity.

A study conducted by Muhammad Faris Kamil resulted in the finding that one of the negative effects of the gadget was anti-social which occurred because someone felt that gadgets were an important thing in his life, resulting in ignorance around him. They rarely interact with people around them(Kamil, 2016). With these findings, it is interesting to analyze the use of social media related to social movements, in the context of charity.

This research explores the social movements carried out by social media, more specifically Instagram, namely @ketimbang.ngemis.yogyakarta, in relation to social movement messages from their uploads, as well as reception messages of social movements among Instagram users. Therefore, before exploring the reception of the followers, we studied the messages from the photos.

\section{Theoretical Framework}

Instagram consists of two words, which are "Insta" and "Gram". The meaning of the first word is taken from the term "Instant" or completely fast or easy. However, in the history of the use of photo cameras, the term "Instant" is another designation 
of a Polaroid camera, a type of camera that can directly print photos a few moments after aiming at an object. Then the word "Gram" is taken from "Telegram" where the meaning is associated as a very fast medium for sending information. Based on the meaning of the words that compose it, Instagram can be referred to as a medium that displays photos and can spread quickly (Atmoko, 2012).

Instagram is a social network born from a company called Burbn, Inc. which was established on October 6, 2010. The company was founded by Kevin Systrom and Mike Krieger. The two CEOs decided to focus more on Burbn on applications that allow users to share photos and videos, comment, and also the ability to like a photo.

This application is the forerunner of Instagram. On April 9, 2012, official Facebook took over Instagram for almost \$ 1 billion in cash and shares. Share photos and videos, comments, and likes, explore, Instagram Stories, and IGTV are Instagram mainstay features that support the communication process between users (Sendari, 2019).

Through these features, Instagram users are greatly facilitated to be able to communicate with other users, even they can create their own world with their own terms and conditions. Not only is it able to support communication between users, Instagram with its features can be a channel for someone to express themselves, so that they can have an identity that can be different from their identity in the real world (Gündüz, 2017; O'Donnell, 2018).

On the other side, according to Castells, the network society, in the simplest terms, is a social structure based on networks operated by information and communication technologies based in microelectronics and digital computer networks that generate process, and distribute information on the basis of the knowledge accumulated in the nodes of the networks (Castells, 2005).

Several studies related to network society have been carried out by several experts. One of them is related to the determinants of network society. A study was conducted by Muhammad Rustam related to network society in communication using a website in South Sulawesi. In his study, it was found that age and education levels did not significantly influence the determination of the types of habits in social media access (Rustam, 2017).

Another study focuses on the claim of how social media users tend to be less social than the people who have social interaction more than online interaction. Humida (2015) found that when teens spend most of their time using social media, it doesn't mean that they are less social. They can be considered as having a high participation in social media, where there is a cultural effect regarding the sociality. Most teens aren't addicted to social media, but they are addicted to their friends. Therefore, the network society that is formed between them when they use social media is simply because they need to socialize with their friends.

\section{Social Movement and Instagram}

Social movements are the key to social change in the world. Although not all social changes always originate from social movements, social movements are unique because there is a group of people who together achieve a common goal, especially those who are outside the sphere of political interests (Johnston, 2014). Social movements are also be understood as a set of beliefs and actions that are not institutionalized carried out by a group of people to advance or deter change in society (Mirsel, 2004). Moreover, Turner and Killian (1987) as cited in Diani defines social movements as a peculiar kind of collective behaviour, which is contrasted to organizational and institutional behaviour.

They said that a social movement as a collectivity acting with some continuity to promote or resist a change in the society or organisation of which it is part. As a collectivity a movement is a group with indefinite and shifting membership and with a leadership whose position is determined more by the informal response of adherents than by formal procedures for legitimising authority (Diani, 1992).

Movements carried out through social media include new social movements, which have an understanding of the types of social movements that have a new, even unique character appearance. Della-Porta \& Diani (Della-Porta \& Diani, 2009) also explained that social movements in new media centered on non-material goals by emphasizing changes in lifestyle and culture rather than encouraging specific changes in public policy or economic change.

In relation to social movements carried out with the involvement of social media, Dewantara and Widhyharto (Dewantara \& Widhyharto, 2015) conducted a study on young people in Yogyakarta. The findings of the study are that the Yogyakarta Society has successfully made the best use of social media as a means of balancing, reminder, and supplement the new youth movement .

Another study of social media as a strategy in social movements has also been carried out, especially those relating to the movement against 
reclamation. From the study, it was concluded that social media succeeded in transforming public issues into political agendas when they were able to build anger at the grassroots level through the role of reason and reflection of movement actors, having strong political commitments, establishing real support with local groups defended, and continuously interact face to face in real space (Galuh, 2016).

\section{Message Reception Theory from Stuart Hall}

In the communication process, there is an encoding and decoding process that involves receiving messages, processing them, and understanding the message among the audience. This is very important because the core of the communication process is the mutual understanding between the sender of the message and the recipient of the message. Therefore, the message conveyed is not enough for an effective communication process. The recipient of the message must have the exact same understanding of the message he received as what the sender of the message wants to convey.

In the process of receiving messages, especially in the decoding process, there are three forms of receiving messages among the audience. Stuart Hall holds out the possibility that the powerless may be obstinate by resisting the dominant ideology and translating the message in a way that's more congenial to their own interests. Three decoding options outline: (1) Operating inside the dominant code. The media produces the message; the masses consume it. The audience reading coincides with the preferred reading; (2) Applying a negotiable code. The audience assimilates the leading ideology in general but opposes its application in specific cases; (3) Substituting oppositional code. The audience sees through the establishment of an organized effort to demythologize the news (Griffin, 2012).

The study of audience's receiption of messages has been carried out by several researchers. One of them is is about the reception of messages related to the portrayal of Javanese people carried in the Suara Merdeka newspaper (Hadi, 2014). The Javanese Semarang depiction contained in the article in the 'Rame Kondhe' rubric in the print media was received by the readers in their context in a position of dominant hegemony which agreed that the characteristics of the characters in the Rame Kondhe rubric were a reflection of native Semarang people.

In addition to the context of print media, the study of message reception using Stuart Hall's theory is also conducted on audio-visual media, namely music videos published via Youtube.
Avriyanty examines how Youtube users receive messages about gender construction in the music video If I Were A Boy by Beyonce Knowles. The study found that youtube users tend to act in a dominant-hegemonic position. The song is close to most of it, every girl relates to her opposite sex, which is in equal and have negative stereotype (Avriyanty, 2011).

A study related to receiving messages from audio-visuals, namely films, has also been carried out, the Aladdin film (Purnamasari, 2020). It was found that there is a change in parental communication patterns to more open and dynamic ones due to the era of media and information openness. In general, informants are in a situation of negotiation with no emphasis on cultural background, but based more on religious issues. Based on studies of the reception of messages in the above audiences, it can be seen that the messages regarding social movements found on social media through their uploads have not been widely studied by researchers. In fact, the message about this social movement has been widely voiced through social media. Communities are no longer merely part of real society but also part of the virtual community.

\section{Material and Methodology}

This study is qualitative descriptive, with the aim of understanding the phenomena experienced by research subjects holistically. Descriptions in the form of words and language are dominant in this type of research, and natural contexts are the characteristics that distinguish them from experimental type research (Neuman, 2014). This study uses data collection technique through the study of documents, based on the definition of documents by Bungin's conception which states that even data from news media can be classified as documents (Bungin, 2008). In the context of this study, the documents are the posts of @ketimbang.ngemis.yogyakarta Instagram account, more specifically five posts with the highest social engagement, which can be seen from the most 'like'.

Moreover, data of this study were also collected by conducting interviews with the informants through the data collection technique. This technique is needed to reveal the audiences' reception of the social change message in the posts of @ketimbang.ngemis.yogyakarta. However, because researchers have no knowledge of the specified criteria, the sampling technique in this study is snowball sampling (Neuman, 2014). Furthermore, the technical analysis used in this study is qualitative content analysis and interactive 
analysis, in accordance with the concept of Miles \& Huberman quoted by Neuman (Neuman, 2014).

This research is conducted in two stages. The first stage is the process of collecting data through uploads in the object of research, Instagram account@ketimbang.ngemis.yogyakarta. In the process of collecting the data, researchers manually checked the uploads of this account. Since this account appeared, on June 21, 2015, until the time of data collection, on October 2, 2017, there were 236 uploads, 40 of which were photos of figures representing the perseverance of elderly people who still work. Of the 40 photos, five photos were taken with the most likes. Furthermore, the uploads are analyzed based on the photos and captions, especially to obtain data on social movements.

Furthermore, in the second stage, the process of data collection was carried out by interviewing a number of informants, using the snowball sampling technique, because the researchers had no knowledge of Instagram @ ketimbang.ngemis.yogyakarta. The first informant interviewed was the administrator of @ketimbang.ngemis.yogyakarta who was contacted via Instagram direct message. From the first informant, eight informants were involved in this research. Data from the interviews were analyzed using the concept of receiving decoding messages from Stuart Hall.

\section{Result and Discussion}

This section is divided into two parts. The first part is a discussion on the contents of social movement messages on Instagram @ ketimbang.ngemis.yogyakarta, from the photos and captions. The second part is a discussion on audiences' reception of the message of social movements in the account @ ketimbang.ngemis.yogyakarta.

All of the five photos that are the objects of this research show the figures of elderlies who were doing work. Four of them are grandmothers who were selling sandals, beans, cotton candy, and crackers, while the other photo shows a grandfather, who sold and repaired secondhand watches. Technically, the photos are of good quality, with high resolution and sharpness. Moreover, aesthetically, the five photos that are the objects of this study followed the rules of thirds technique. Grill \& Scanlon, as cited by Liu et.al. (Liu et al., 2010) defines that in this technique, the image is divided into nine equal parts by two equally spaced horizontal lines and two such vertical linesas can be seen in figure 1 .

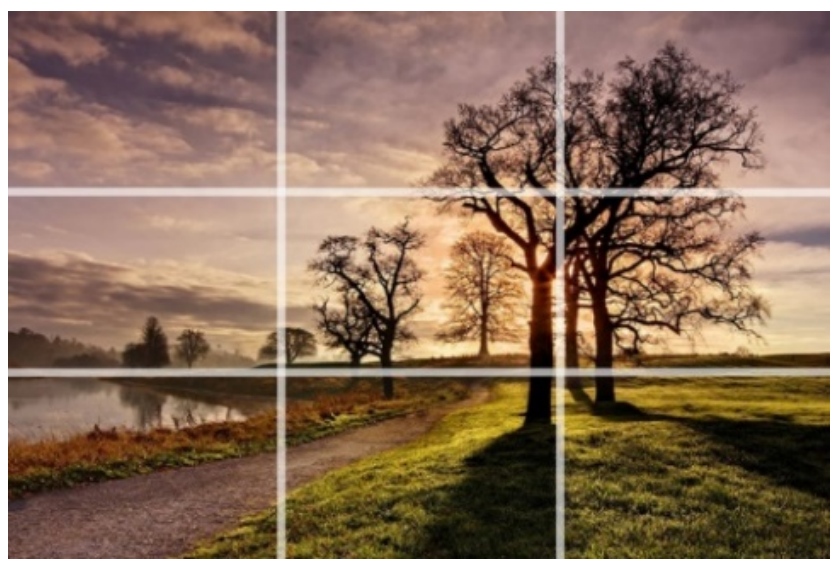

Figure 1. Rule of thirds technique

Source: PetaPixel.com

In simple terms, the rules of thirds technique implemented in the photo that was studied in this study appear in the position of the photo object that is not right in the middle of the photo, as seen in the photo of the grandfather. In figure 2 , it can be seen that grandfather Projo's position is on the edge of the photo, which is technically in accordance with the rule of thirds. Photos that are aesthetically attractive will certainly draw more attention from the audience. So, in the context of this photo in the @ ketimbang.ngemis.yogyakarta, it is assumed that they will be able to draw the attention of Instagram users who have access to these photos. Results and discussion contain results obtained by the author during the research. 


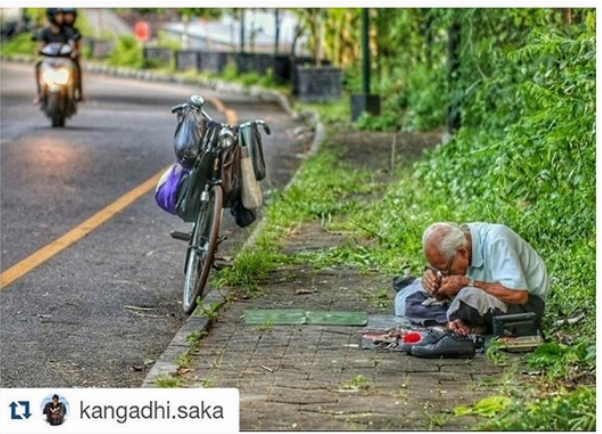

Figure 2. Grandfather Projo

Source: @ketimbang.ngemis.yogyakarta

Furthermore, the analysis of the photos that become the objects of this study was carried out by looking at the facial expressions of the characters in the photos. Facial expression is a form of nonverbal communication. Paul Ekman, as cited in Manusov, says that the display of some emotions is universal, with about six emotions exhibited on people's faces in similar ways across cultures. Specifically, there are six universal emotions that will be decoded similarly to others' faces, which are anger, disgust, fear, happiness, sadness, and surprise (Manusov, 2016). In the photos, the expression of sadness was highly represented, by looking at their facial expression, like in figure 3.

Sadness is a feeling experienced by someone when they cannot get what they want. The sadness seen in the photo shows that the grandmother, who sells the peanut actually felt that her life was in trouble. This photo does not directly indicate the existence of social movements or invitation for social movements. However, this photo could be a stimulus for someone or a group of people to get involved in social movements which generally try to free elderly people whose lives are in distress.

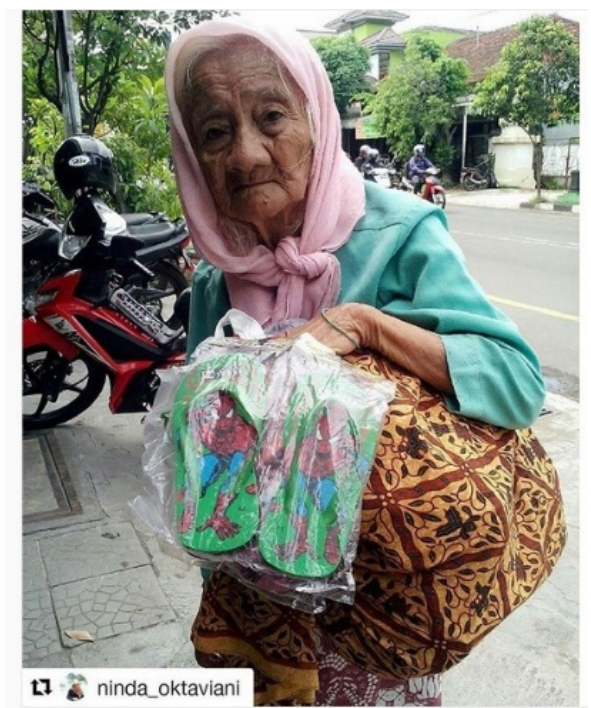

Figure 4. Grandmother Karyo Source: @ketimbang.ngemis.yogyakarta

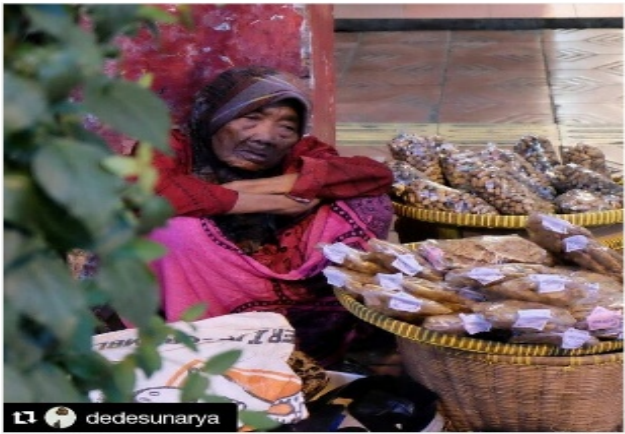

Figure 3. grandmother who sells peanuts Source: @ketimbang.ngemis.yogyakarta

This is consistent with one of the studies of social movements, especially in classical and neoclassical traditions which emphasize orientation towards mass society theory (Rusmanto, 2013). The study on this theme leads to the perspective of movement studies on a situation in society, which is caused by the marginalization of individuals from fixed social groups and makes them more vulnerable to protests or complaints in a community movement. Specifically, this study focuses on individual conditions such as alienation and cultural conditions such as disorder.

Other photos are also the same as those of the grandmother who sells peanuts. The expression of sadness was also seen on the faces of the characters in the other photos on the object of this study, especially the photos of grandmother Karyo (figure 4) and a photo of grandmother Sujiyem (figure 5). The two grandmothers showed sad facial expressions, but the photos also showed their commodities, namely cotton candy and sandals. The two photos also do not specifically indicate the activities of social movements or the invitation to do social movements.

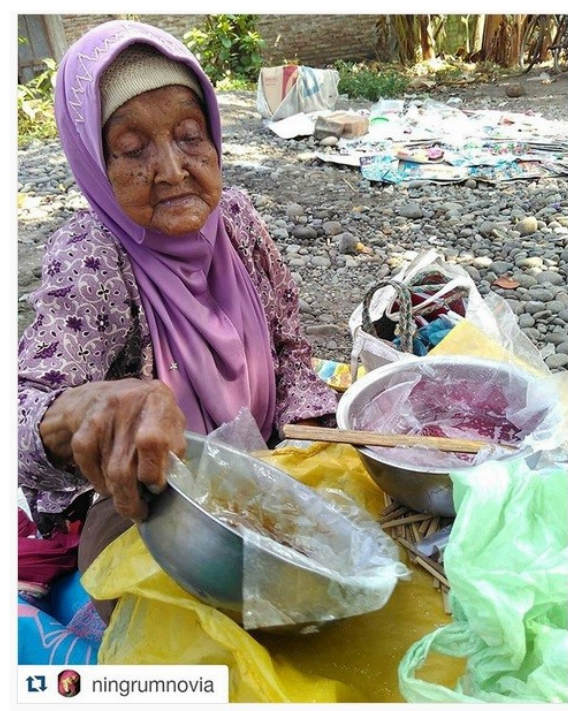

Figure 5. Grandmother Sujiyem Source: @ketimbang.ngemis.yogyakarta 
In figure 4 we can see a sadness on the face of grandmother Karyo. It can be seen from her frowning forehead and downward gaze, as if her sadness was too great. However, the photo also shows the traditional cotton candy that she had prepared for the buyer. As shown in figure 54, the sad facial expression can be seen from the absence of smile or laugh on her face. Moreover, she also looks so tired. This can be assumed that she is tired of going through her life until her old time. However, once again, this photo also shows that she has the passion to keep her activities by selling sandals. Figure 6 shows the photo of a grandmother selling crackers. She looks happy by showing a slight smile on her old yet tired face. It shows with all of the shortage the grandmother still feels optimistic about her life.

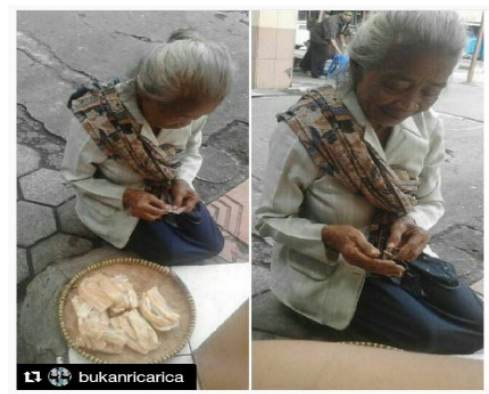

Figure 6. Grandmother who sells crackers Source: @ketimbang.ngemis.yogyakarta

All of the photos used as the research objects show a picture of the struggling efforts of some elderly in going through their daily lives. With all of the shortages they experienced, their spirit to lead their daily lives by selling several things can inspire other people who look at these photos.

Besides the photos, the caption of the posts was also analyzed to reveal the message of the posts, specifically regarding the social movement. In general, the caption of all of the photos does not have an indication of social movement or the invitation to do a social movement explicitly. There is also no jargon that is explicitly shown. However, it implies social movement as the caption describes the condition of the figures in detail.

For example, the caption in figure 5. It explains the condition of grandmother Sujiyem who has to walk approximately 60 kilometers every day to sell the sandals. She decided not to go by bus so that she walked while offering the sandals. At the age of 86 , she still has the spirit to work. Meanwhile, figure 1 shows grandfather Projo who is very serious about his work even though he has a problem with his visual ability. However, he remains enthusiastic and stays focused on the watches he is working on. Everyday he opens his stall in the Kotabaru area. But not only does he stop at the stall but also he sometimes goes around selling used watches and repairing watches. Sometimes he also buys broken watches to be repaired and then resold. No one knows exactly how old he is, because he has been going senile.

Those two photos provide a caption that explains the detail of the figures in the photos. There are no words or sentences that indicate a social movement or an invitation to do the social movement specifically. However, the description is able to imply it.

\section{Message Reception about Social Movement}

There are three types of reception messages based on Hall's conception. The first type is the dominant typeor hegemonic code. The audiences' position in this type is directly approving what is presented by the media, accepts the full ideology of the program without any rejection or disapproval of it. In this study, the dominant type is meant to be informants who immediately believe in each of the information that is posted in @ ketimbang.ngemis.yogyakarta rather than finding other information from other sources.

From the interview, there are several informant opinions that matched this category:

\section{“...karena bisa lebih mengundang empati langsung aja gitu mba...” (informant 1) ["... because it can invite more direct empathy..." (informant 1)]}

"Kalo saya sih biasanya langsung aja percaya, soalnya admin KNY juga ga mungkin langsung post begitu aja" (Informant 4)["I usually believe it immediately, because it is impossible for the KNY admin to post it without consideration (Informant 4)]

The second type is negotiated code, where the audience mixes their interpretation with their particular social experiences. The audience in this negotiation category acts between adapting and 
being opposed to message interpretation or ideology in the media. In this study, the negotiated type is meant to be an informant who does not directly believe in uploaded information but can change their attitudes to believe after going through the stage of looking for more information through direct experience by checking the information from other followers as part of the network society in Instagram which are then reposted by the administrator or by having direct observations to the places where noble figures sell. Most of the informants were in this type, as can be seen as follows:

"Aku tuh cuman pengen memastikan aja gitu mba, soalnya aku dulu tuh tipe orang yang kayak gini nih ada komunitas yang begini tapi kurang percaya, ini beneran ga ya disalurin gitu, jadi kayak pengen terjun langsung aja dan melihat realitanya gimana" (Informant 2).

["I just want to make sure, because I used to be the type of person like this, when I know this kind of community, but I don't trust them right away. I mean with the donation, so I just want to get involved in this kind of community directly and find out how is the reality" (informant 2).]

"Pengen lebih tau detailnya sosok itu loh mba, kayak pengen tau rumah sosoknya gitu.

Pengen tau detail pas ngebantu aja" (Informant 3).

["I want to know more about the figure, want to get to know them, know their houses, just want to know the detail when I help them" (Informant 3).]

"Biasanya saya baca satu-satu dulu sih mba, saya teliti dulu gitu" (Informant 5).

["I usually read them thoroughly. I gather the information one by one" (Informant 5).]

"Saya sih biasanya kroscek dulu mba sama admin lain" (Informant 7).

["I usually do the re-check by contacting other administrators" (Informant 7).]

“...cuman ya caption harus jelas aja gitu intinya jual apa, lokasi mana, kalo bisa harga jualnya berapa trus ditambahin deh tuh info-info pendukung..." (Informant 8).

[".. well, the caption must be clear. It must say what commodities they sell, where do they sell them, what is the price, and it will be great if there are some supporting information" (Informant 8).]
Finally, the third type is oppositional code. It happens when the audience is opposed to the representation offered in the show in a way that is different from the reading that has been offered. In this study the oppositional type is an informant who does not believe in all uploaded information, even though he has gone through the stage of seeking further information, the informant still shows an attitude of disbelief in all forms of uploaded information. In this study, no informants were found with oppositional type.

\section{Conclusions}

Based on the analysis of the posts of @ketimbang.ngemis.yogyakarta Instagram account, it was found that there were changes, the presence of new symptoms in social movements. The past social movements tended to be more vulgar, demonstrative, and used jargon that ignited the spirit of the masses. However, nowadays, with the involvement of communication technology through social media and networks society in it, the use of photos that show marginalized groups can attract sympathy, empathy, and attention to the social media community which can be an initial phase of the social movement.

In addition, from the analysis, it is can also be concluded that the audiences in receiving the message about social movement in @ ketimbang.ngemis.yogyakarta are dominated by the second type, which is negotiated code. It means that mostly they will try to find another additional information either by observing it themselves or getting it from their network in Instagram as the part of network society to corroborate the information they got from the posts.

\section{References}

Amenta, E., \& Caren, N. (2006). The Legislative, Organizational, and Beneficiary Consequences of State-Oriented Challengers. In D. A. Snow, S. A. Soule, \& H. Kriesi (Eds.), The Blackwell Companion to Social Movements (pp. 461-488). Blackwell Publishing.

Atmoko, B. D. (2012). Instagram Handbook. Media Kita.

Avriyanty, R. (2011). Analysis of Audience Reception on Youtube toward Gender Construction in the Music Video If I Were a Boy by Beyonce Knowles Ria Avriyanty. Jurnal Kajian Budaya, 2(1), 88-104.

Berberoglu, B. (2019). Introduction: Dynamics of Social Movements, Revolution, and Social Transformation. In B. Berberoglu (Ed.), The Palgrave Handbook of Social Movements, Revolution, and Social Transformation (pp. 
1-13). Palgrave Macmillan.

Bungin, B. (2008). Penelitian Kualitatif; Komunikasi, Ekonomi, Kebijakan Publik, dan Ilmu Sosial Lainnya. Kencana.

Castells, M. (2005). The Network Society: from Knowledge to Policy. In M. Castells \& G. Cardoso (Eds.), The Network Society: from Knowledge to Policy. Johns Hopkins Center for Transatlantic Relations.

Della-Porta, D., \& Diani, M. (2009). Social Movements: An Introduction (2nd ed.). Wiley-Blackwell.

Dewantara, R. W., \& Widhyharto, D. S. (2015). Aktivisme dan kesukarelawanan dalam media sosial komunitas kaum muda Yogyakarta. Jurnal Ilmu Sosial Dan Ilmu Politik, 19(1), 40-52.

Diani, M. (1992). The concept of social movement. The Sociological Review, 40(1), 1-25. https://doi.org/10.4324/9781315260143-15

Galuh, I. G. A. A. K. (2016). Media Sosial sebagai Strategi Gerakan Bali Tolak Reklamasi. Jurnal Ilmu Komunikasi, 13(1), 73-92.

Griffin, E. M. (2012). A First Look at Communication Theory (8th ed.). McGrawHill.

Gündüz, U. (2017). The Effect of Social Media on Identity Construction. Mediterranean Journal of Social Sciences, 8(5), 85-92. https://doi.org/10.1515/mjss-2017-0026

Hadi, M. Z. (2014). Pemaknaan Khalayak terhadap Penggambaran Orang Jawa Semarang dalam Rubrik Rame Kondhe di Harian Suara Merdeka Summary Skripsi Penyusun Nama NIM: Mirtsa Zahara Hadi. Universitas Diponegoro.

Humida, T. (2015). New Media and Network Society: Teens Are More Into Social MediaIs That Addiction? IOSR Journal Of Humanities And Social Science (IOSR-JHSS, 20(3), 68 . https://doi.org/10.9790/083720386878

Johnston, H. (2014). What Is A Social Movement? Polity Press.

Kamil, M. F. (2016). Pengaruh Gadget Berdampak Kepada Kurangnya Komunikasi Tatap Muka Dalam Kehidupan Sehari [IAIN Raden Intan Lampung].

http://repository.radenintan.ac.id/437/1/SKR IPSI.pdf

Kemp, S. (2020). Digital 2020: 3.8 Billion People Use Social Media Media. We Are Social. https://wearesocial.com/blog/2020/01/digital -2020-3-8-billion-people-use-social-media

Lim, M. (2003). The Internet, Social Networks, and Reform in Indonesia The Internet: A Convivial Medium for Civil Society. In N.
Couldry \& J. Curran (Eds.), Contesting Media Power: Alternative Media in A Networked World (pp. 273-288). Rowman and Littlefield.

Liu, L., Chen, R., Wolf, L., \& Cohen-Or, D. (2010). Optimizing photo composition. Computer Graphics Forum, 29(2), 469-478. https://doi.org/10.1111/j.1467-

8659.2009.01616.x

Manusov, V. (2016). Facial Expressions. In C. R. Berger \& M. E. Roloff (Eds.), The International Encyclopedia of Interpersonal Communication (1st ed., pp. 1-7). John Wiley \& Sons, Inc. https://doi.org/10.1002/9781118540190.wbe ic 105

Mirsel, R. (2004). Teori Pergerakan Sosial. Resist Book.

Nash, J. (2004). Social movements: an anthropological reader. Blackwell Publishing.

https://doi.org/10.1016/j.clinimag.2008.05.0 01

Neuman, W. L. (2014). Social Research Methods: Qualitative and Quantitative Approaches. In Teaching Sociology (7th ed., Vol. 30, Issue 3). Pearson Educated Limited. https://doi.org/10.2307/3211488

O'Donnell, N. H. (2018). Storied Lives on Instagram: Factors Associated With the Need for Personal-Visual Identity. Visual Communication Quarterly, 25(3), 131-142. https://doi.org/10.1080/15551393.2018.1490 186

Parahita, G. D. (2019). The Rise of Indonesian Feminist Activism on Social Media. Jurnal Komunikasi Ikatan Sarjana Komunikasi Indonesia, 4(2), 104-115. https://doi.org/10.25008/jkiski.v4i2.331

Purnamasari, N. I. (2020). Audience Reception Related to Freedom of Life Partner in Aladdin Film. Jurnal Komunikasi Ikatan Sarjana Komunikasi Indonesia, 5(1), 31-41.

Reinmurth, D. (2016). Judith Butler and The Politics of Protest. In J. Roose \& H. Dietz (Eds.), Social Theory and Social Movements: Mutual Inspirations (pp. 135-154). Springer.

Rusmanto, J. (2013). Gerakan Sosial: Sejarah Perkembangan Teori Antara Kekuatan dan Kelemahannya. Zifatama Publishing.

Rustam, M. (2017). Network Society, Internet, dan Aktivitas Komunikasi Masyarakat (Survai Aktivitas Komunikasi Masyarakat melalui social Network websites di Kelurahan Tamalanrea Indah Kecamatan Tamalanrea Kota Makassar Provinsi Sulawesi Selatan). Jurnal Studi Komunikasi Dan Media, 21(2), 
$165-180$.

Sendari, A. A. (2019). Instagram Adalah Platform Berbagi Foto dan Video, Ini Deretan Fitur Canggihnya.

Liputan6.Com. https://www.liputan6.com/tekno/read/39067 36/instagram-adalah-platform-berbagi-fotodan-video-ini-deretan-fitur-

canggihnya\#: : :text=Fitur yang paling utama dari,dan video kepada pengguna lainnya.\&text=pengguna dapat memberikan caption dan,yang terlibat dala

Subramanian, K. R. (2017). Influence of social media in recruiting talents. International Journal of Scientific Progress and Research (IJSPR), 38(109), 70-75.

The Jakarta Post. (2019). Indonesia has 171 million internet users: Study. The Jakarta Post. https://www.thejakartapost.com/life/2019/05 /18/indonesia-has-171-million-internetusers-study.html 